\title{
BIOETHANOL PRODUCTION FROM LIQUID WASTE OF RICE FLOUR WITH BATCH PROCESS
}

\author{
Sari Ni Ketut*, Sutiyono S, Luluk E, Ernawati Dira, Wesen Putu, Tatik Sri Hajati \\ University of Pembangunan Nasional "Veteran" Jawa Timur, Surabaya, East Java, Indonesia \\ E-Mail: sari_ketut@yahoo.com
}

\begin{abstract}
Liquid waste rice flour is abundant liquid wastes but it is still underutilized. So far, it is only used for process water in factory production, wastewater, and even regarded as environment pollution. Rice flour liquid waste has higher levels of glucose, starch and protein which can be used as one of ethanol producers. This study aims to assess the process of hydrolysis, fermentation, and batch distillation process, as well as to search for alternative raw materials products of bioethanol. There are three processes of making bioethanol, namely biological hydrolysis process done by using bacillus; the process of fermentation by using Saccharomyces cerevisiae (SC); and batch distillation. After the third process was done, the results were: glucose is $5 \%-10 \%$ in the process of hydrolysis; ethanol content is $11 \%-16 \%$ in the fermentation process; and the levels are high enough for bio-ethanol, which is $95 \%-96 \%$ in the batch distillation process. So it can be concluded that the liquid waste of rice flour can be used as raw materials for the manufacture of alternative bioethanol.
\end{abstract}

Keywords: batch distillation, fermentation, hydrolysis, liquid waste of rise flour

\section{INTRODUCTION}

Bioethanol is obtained from biomass and bioenergy crops proposed as one viable alternative to gasoline (Demirbas, 2011). Lignocellulosic biomass is one of the main potential sources for the production of bioethanol global economy. Agriculture, forestry (soft wood and hard wood) and industrial waste are major lignocellulosic biomasses (Limayem et al., 2012). Balat et al., (2008) investigated the production of bioethanol from lignocellulosic biomass using process pretreatment, hydrolysis, fermentation and recovery of ethanol, thus obtained ethanol to levels below $16 \%$, with a further distillation process obtained a $95-96 \%$ ethanol content.

The research by Nibedita et al., (2012) on production of bioethanol from agricultural waste using PROFER pretreatment method reported an increase of the concentration of fermentable sugar after saccharification enzyme process. The conversion of glucose and xylose fermentation to ethanol requires new technologies, in order to obtain ethanol levels below $16 \%$.

Research of Saravana et al., (2014) on production of bioethanol from sago pith waste (SPW) using microwave hydrothermal catalytic hydrolysis with carbon dioxide gave a result of higher energy savings compared to previous techniques without enzyme, acid or alkaline catalyst, deriving $15.6 \%$ ethanol content.

Starch is a component that is more complex than a disaccharide. Before undergoing a fermentation process, the starch must be broken by using the amylase enzyme and form a disaccharide maltose component. Using enzymes, maltase and maltose, starch is hydrolysed into glucose (Karimi et al., 2006). The reaction formula of glucose from starch is as follows:

$$
\begin{array}{ll}
\left(\mathrm{C}_{6} \mathrm{H}_{10} \mathrm{O}_{5}\right)_{n}+\frac{1}{2} n \mathrm{H}_{2} \mathrm{O} & \underset{\text { Amylase }}{\stackrel{\text { Enzyme }}{\longrightarrow}} \frac{1}{2} n \mathrm{C}_{12} \mathrm{H}_{22} \mathrm{O}_{11} \\
\frac{1}{2} n \mathrm{C}_{12} \mathrm{H}_{22} \mathrm{O}_{11}+\frac{1}{2} n \mathrm{H}_{2} \mathrm{O} & \stackrel{\text { Enzyme }}{\stackrel{\text { Maltase }}{\longrightarrow}} \frac{1}{2} n \mathrm{C}_{6} \mathrm{H}_{12} \mathrm{O}_{6}
\end{array}
$$

Processes performed in this research were pretreatment, chemical or enzymatic hydrolysis, fermentation and product separation or distillation. With a proper pretreatment strategy on hydrolysis enzyme, it can increase the efficiency of lignocellulosic biomass and lignin inhibiting the saccharification process. Various pretreatment approach has been used in the past such as using acid or alkaline, hydrogen peroxide, steam explosion, hot liquid, ammonia fiber expansion pretreatment (Teymouri et al., 2005), sodium chorite pretreatment (Kumar et al., 2009) and biological pretreatment. The purpose of using dilute acid pretreatment is to remove the hemicellulose and sugar recovery component. Among all the methods of pretreatment, acid pretreatment method of biomass with dilute sulfuric acid has long been recognized as an important step to eliminate the hemicellulosic fraction of lignocellulosic substrates conserve biological conversion of cellulosic biomass into ethanol (Kuhad et al., 2010).

Research of Alok et al., (2012) suggested the acid pretreatment of waste paper hydrolized as raw material for production of bioethanol can optimize sulfuric acid hydrolysis and hydrolized acid fermentation paper waste process with Pichia stipites, thus obtained ethanol content of $77.54 \%$. With an additional distillation process, it obtained $95-96 \%$ ethanol content.

The fermentation process is affected by microorganisms and requires good nutrition to get a good fermentation. Proper nutrition for microorganisms is nitrogen which can be obtained from the addition of NH3, ammonium salts, peptone, amino acids and urea, liquid Nitrogen is needed to $400-1000 \mathrm{~g} / 1000 \mathrm{~L}$, Phosphate is needed for $400 \mathrm{~g} / 1000 \mathrm{~L}$ (Kuhad et al., 2010).

In the fermentation process, glucose is converted to ethanol with the following reaction:

$$
\underset{\text { Glucose }}{\mathrm{C}_{6} \mathrm{H}_{12} \mathrm{O}_{6}} \longrightarrow \underset{\text { Ethanol }}{2 \mathrm{C}_{2} \mathrm{H}_{5} \mathrm{OH}+2 \mathrm{CO}_{2}}
$$

Equation (1) is a Differential-algebraic-model equation (Daes) for batch distillation of multi-component system, assuming no form of two liquid phases. The 
above equation is a forward-finite-difference, which will be acquired under the liquid composition $(x i, j+1)$ as a function of $\Delta \xi$ (dimensionless time), which is obtained as follows (Henley et al., 1998):

$$
\mathrm{x}_{\mathrm{i}, \mathrm{j}+1}=\mathrm{x}_{\mathrm{i}, \mathrm{j}}+\left(\mathrm{y}_{\mathrm{i}, \mathrm{j}}-\mathrm{x}_{\mathrm{i}, \mathrm{j}}\right) \Delta \xi
$$

Where the composition of the initial liquid in the bottom $\left(\mathrm{x}_{i, j}\right)$ and $\Delta \xi$ were determined, while the vapor composition $\left(\mathrm{y}_{\mathrm{i}, \mathrm{j}}\right)$ is calculated using the equation bubble $\mathrm{T}$ (Henley et al., 1998).

Predecessor researchers for bioethanol made from starch have obtained quite good cellulose and bioethanol results. The purpose of this study was to look for alternative raw materials, reviewing the process of hydrolysis, fermentation, and batch distillation process to produce bioethanol with high ethanol content. In this research, we located raw materials from wastewater, using three processes (hydrolysis, fermentation and distillation batch) simultaneously and attained bioethanol production levels of $95-96 \%$ ethanol as substitute materials.

\section{METHODOLOGY}

From the results of laboratory analysis, it is known that ethanol-forming elements are glucose and starch. The average concentration of glucose is about $6 \%$, starch in the rice is about $79 \%$, while the starch in the rice flour wastewater is quite high, about $30 \%$.

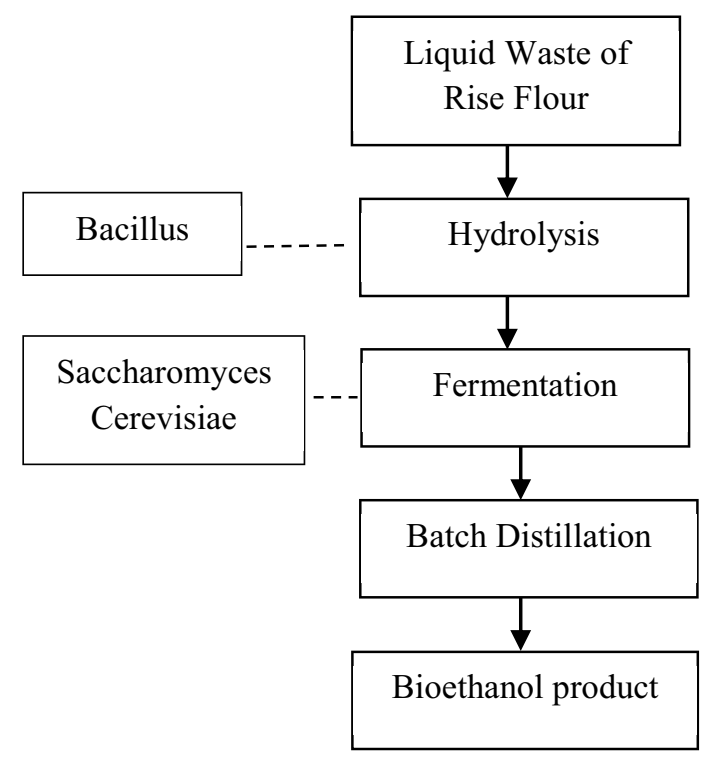

Figure-1. Chronology of bioethanol production using hydrolysis, fermentation and distillation batch

Pre-treatment was performed using waste water and filtration of plant rice flour to get a high glucose and starch and the hydrolysis process with the bacillus. A good quality bioethanol product is determined from several parameters, such as the degree of acidity $(\mathrm{pH})$, Bacillus ratio for rice flour mill effluent, SC starter concentration, time of fermentation, and batch distillation time.

Quality analysis for raw materials and products of bioethanol was performed through laboratory work. The analysis was carried out by instrumentation and gravimetry, using Gas Chromatography (GC) and
Spectrophotometer, which analyzed the concentration of starch, glucose, ethanol, crude protein and $\mathrm{N}, \mathrm{P}, \mathrm{K}, \mathrm{Ca}$, $\mathrm{Mg}, \mathrm{S}$.

\section{Hydrolysis process procedure}

Hydrolysis process at figure 1 was performed under the following conditions: a temperature of $30^{\circ} \mathrm{C}$, hydrolysis time of 1 hour with 200 rotations per minute (rpm). The varied conditions were: the ratios of the volume of liquid waste bacillus were $1: 2 ; 5: 4 ; 10: 7$ and volume of: $5,7,9,11$, and $13(\% \mathrm{v} / \mathrm{v})$. Once the process is completed, we obtained filtrate and solids. The filtrate would be processed using fermentation to obtain ethanol and solids levels can then be used as composts.

\section{Fermentation process procedure}

The result of glucose hydrolysis process has not qualified yet, so the next step is adding citric acid or $\mathrm{NaOH}$. Citric acid is added to the filtrate until it reached a fermentation $\mathrm{pH}$ of 4.5 , approximately. Next is adding the starter to the fermented solution in an anaerobic condition. In the fermentation process (Figure 1), the permanent conditions were a temperature of $30^{\circ} \mathrm{C}, \mathrm{pH}$ of 4.5 ; and the fermentation volume is equal to the amount of filtrate volume of hydrolysis process results. The changed conditions were varying the ratios of the volume of Bacillus waste which were: $1: 2 ; 5: 4$; and 10:7 with the addition of Saccharomyces cereviceae of: $5,7,9,11$, and $13(\% \mathrm{v} / \mathrm{v})$ and fermentation time of 4, 6, 8, 10, and 12 days, then continued with performing ethanol level analysis.

\section{Distillation process procedure}

Results obtained from the fermentation were inserted into the distillation flasks to obtain ethanol from glucose. Batch distillation process as shown in Figure 1 was run at a temperature of $78^{\circ} \mathrm{C}$, equipped with a total condenser and heater. After the volume of the solution reached $10 \%$ of the volume of bottom feed, the batch distillation was stopped, and then the solution was analyzed for its level of ethanol.

\section{RESULTS AND DISCUSSION Quality Raw Materials}

Liquid waste used as study materials was derived from rice flour waste from PT. Boga Sari mill. Carbohydrates are the main source of calories for humans, apart from protein and fat. Carbohydrates having the chemical formula of $\left(\mathrm{CH}_{2} \mathrm{O}\right)_{\mathrm{n}}$, are formed from the reaction of $\mathrm{CO} 2$ and $\mathrm{H} 2 \mathrm{O}$ with the help of sunlight through the process of photosynthesis in plant cells that contain chlorophyll. Ingredients that are a source of carbohydrates come from roots and stems of plants such as cassava, sago, and sugar cane; whereas from grains are rice, corn and soybeans. Rice flour mill effluent is the raw material came from carbohydrates types of grains, such as rice.

According to the results of laboratory analysis, starch content in rice flour mill effluent is of $9.282 \%$, averagely. This means that if all elements are completely hydrolyzed, a large amount of glucose will be obtained. From 100 liters of liquid waste of rice flour mill, we can produce a maximum of 9.282 liters of glucose. In addition to starch, glucose is also present in the flour wastewater, 
increased in bulk. In 100 grams of flour liquid waste, glucose can be produced to a maximum of 3,786 liters. Noting the high composition of glucose and starch in the flour mill waste water, the hydrolysis process is expected to run perfectly, so that the amount of glucose and starch was actually relegated to 12.568 liter glucose. The process of filtering waste flour mill is done by using gauze and was done repeatedly to get a clean result before going to hydrolysis process. In addition to the natural filtration, sedimentation was also done by keeping it for a while so it would form naturally, and then the filtrate was taken and sedimentation were used as compost sediment.

The effect of $\mathrm{pH}$ on adding $\mathrm{H}-\mathrm{Cl}$ can be determined. With additional volume greater than the $\mathrm{H}-\mathrm{Cl}$, a low $\mathrm{pH}$ would be obtained. Due to the required $\mathrm{pH}$ of the fermentation is 4.5 , the addition of $\mathrm{H}-\mathrm{Cl}$ volume by $7 \% \mathrm{v} / \mathrm{v}$ is the closest, for various volume of wastewater. Before performing the process of hydrolysis, the $\mathrm{pH}$ of the filtrate was measured in accordance with the provisions of the fermentation process which is approximately 4.5. To obtain a $\mathrm{pH}$ of $4.5, \mathrm{Na}-\mathrm{OH}$ was added if the $\mathrm{pH}$ of the filtrate was below 4.5, while citric acid was added if the $\mathrm{pH}$ of the filtrate was above 4.5.

\section{Hydrolysis Process}

Starch is a component that is more complex disaccharide; since starch must be broken using amylase into disaccharide components, such as maltose. By using enzyme or bacillus, maltose is hydrolyzed into glucose.

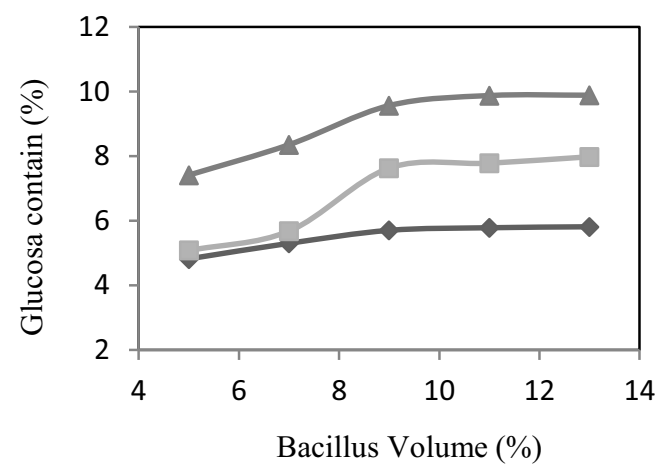

Figure-2. Changes on glucose contains with an addition of bacillus in liquid waste of rice flour (ratio bacillus/volume waste $=1: 2: \bullet$, ratio bacillus $/$ volume waste $=5: 4: \mathbf{m}$, ratio bacillus/volume waste $=10: 7$ :

Figure 2 shows the effect of glucose levels for bacillus volume addition. The greater the volume of bacillus, the higher the level of glucose. On the addition of Bacillus volume above $9 \%$, the graph shows a constant profile, because the performance of Bacillus began to decline and die from time to time, so it would be needed to add more Bacillus. The addition of Bacillus volume between (3-9) \% v/v showed an increase in glucose levels, therefore showing the growth phase of Bacillus, so it can decompose starch into glucose optimally. Before the fermentation process is done, the filtrate optimum glucose level was measured at about $16 \%$; if the glucose level is more than $16 \%$, dilution is done. If the glucose level is less than $16 \%$, the addition of glucose is made.
Fermentation Process

The fermentation process is a fermentation process that does not use oxygen (anaerobic process). To control the production of ethanol from sugar is quite complex. Substrate concentration, oxygen, and ethanol products, all of them affect yeast metabolism, cell survival, cell growth, cell division, and the production of ethanol. Appropriate selection of yeast strains and a high tolerance for concentration substrate or alcohol is important to improve results. The first fermentation is basic maintenance of seeds fermentation or starter preparation. Starter was inoculated until it was ready to be a fermenter, and then put into the fermentation substrate, which used SC seed fermentation.

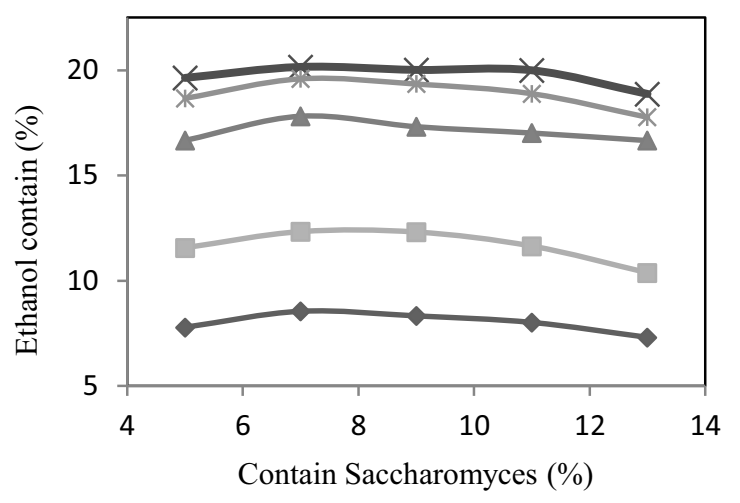

Figure-3. Changes on ethanol contains with an addition of Saccharomyces in liquid waste of rice flour (fermentation time $=4$ days: $\bullet$, fermentation time $=6$ days: $\boldsymbol{\square}$, fermentation time $=8$ days: $\boldsymbol{\Lambda}$, fermentation time $=10$ days: $\mathrm{x}$, fermentation time $=12$ days: $*$ )

Figure 3 shows the level of concentration of the filtrate which affects glucose residue. For a number of 6 , 9, 11 and $13 \% \mathrm{v} / \mathrm{v}$ SC starters, the maximum residual glucose levels will be obtained in $(1.3-3)$. The percentage, as in the reactor tank, of filtrate amount and SC starter were low hydrolyzed, so that the fermentation process is not optimal. By increasing the number of hydrolysis filtrate and SC beginner, residual glucose became smaller, because it has been fermented into ethanol.

After analyzing the residual glucose concentration of the fermentation process, the percentage of $\mathrm{SC}$ of the liquid (filtrate) was examined. In addition of $7 \%$, it showed a smaller residual glucose levels compared to the addition of $6,9,11$ and $13 \%$ starter. In initial research and Journal, an addition of $7 \%$ of the volume of fluid was admitted. The influence of the level of residual filtrate glucose levels, for 6, 9, 11 and $13 \%$ SC starters, a maximum residual glucose level was obtained in (1.5 to $5) \%$. It is because in the reactor tank, the filtrate is hydrolyzed and the SC starter is still low, so the fermentation process is not optimal. With the increasing number of hydrolyzed filtrate and SC starter, the residual glucose becomes smaller, since it was fermented into ethanol. According to preliminary research and the Journal, the best fermentation time is six days. Six days of fermentation is the best because it is the optimum phase of the SC. Below six days, there will be an adjustment to SC 
growth and after six days there will be a regeneration phase or change phase of SC.

\section{Batch Distillation Process}

Ethanol is obtained from the fermentation and distillation batch process of mini-scale plant. By choosing the best condition of fermentation, the fermentation time is 10 days. The concentration of ethanol from distillation batch shows the range of $95 \%$ to $96 \%$ and yield $31.66 \%$ to $33.3 \%$. Economically, it meets the necessary technical requirements of ethanol, which is $95 \%$, and the resulting yield is also high.

Table-1. Ethanol contain and yield on distillation batch

\begin{tabular}{|c|c|c|c|c|c|}
\hline $\begin{array}{l}\text { RatioHCl } \\
\text { to raw } \\
\text { materials }\end{array}$ & $\begin{array}{c}\mathrm{SC} \\
\text { contain } \\
{[\% \mathrm{v} / \mathrm{v}]}\end{array}$ & $\begin{array}{l}\text { Glucose } \\
\text { contain } \\
{[\% \mathrm{v} / \mathrm{v}]}\end{array}$ & $\begin{array}{l}\text { Ethanol } \\
\text { contain } \\
{[\% \mathrm{v} / \mathrm{v}]}\end{array}$ & $\begin{array}{l}\text { Ethanol } \\
\text { contain } \\
{[\% \mathrm{v} / \mathrm{v}]}\end{array}$ & $\begin{array}{l}\text { Yield } \\
\text { [\%] }\end{array}$ \\
\hline \multirow{5}{*}{$1: 2$} & 5 & 4.82 & 19.63 & 91.5 & 30.5 \\
\hline & 7 & 5.30 & 20.15 & 93 & 31,8 \\
\hline & 9 & 5.70 & 20.01 & 94 & 32.3 \\
\hline & 11 & 5.78 & 19.99 & 92.5 & 31.6 \\
\hline & 13 & 5.81 & 18.87 & 91 & 32.3 \\
\hline \multirow{5}{*}{$5: 4$} & 5 & 5.08 & 18.63 & 92 & 30.2 \\
\hline & 7 & 5.68 & 20.46 & 94.5 & 31.8 \\
\hline & 9 & 7.63 & 20.88 & 96 & 33.3 \\
\hline & 11 & 7.78 & 19.33 & 95 & 32.6 \\
\hline & 13 & 7.98 & 18.27 & 94 & 32.1 \\
\hline \multirow{5}{*}{$10: 7$} & 5 & 7.41 & 19.63 & 94 & 30.4 \\
\hline & 7 & 8.35 & 21.9 & 94.5 & 32.8 \\
\hline & 9 & 9.56 & 20.44 & 95 & 33.1 \\
\hline & 11 & 9.87 & 19.66 & 94.5 & 32.9 \\
\hline & 13 & 9.88 & 18.77 & 93 & 32.6 \\
\hline
\end{tabular}

\section{CONCLUSIONS}

Glucose levels of $9.98 \%$ were obtained in the process of hydrolysis of rice flour liquid waste, while ethanol in the fermentation process is $16 \%$ to $20.88 \%$. Raw materials used to produce bioethanol indicate that the levels of ethanol $95 \%$ to $96 \%$ with ethanol yield $31.69 \%$ to $33.3 \%$ can be used to design a batch distillation column. By identifying the concentration and yield of ethanol, the liquid waste of rice flour raw material is more profitable than other raw materials.

\section{ACKNOWLEDGEMENT}

The authors would like to acknowledge the financial support of the Ministry of National Education of the Republic of Indonesia with the National Strategic Competitive Grant, Contract Number: 180/SP2H/PL/DIT.LITABMAS/V/2013.

\section{REFERENCES}

Alok Kumar Dubey, P.K. Gupta, Neelam Garg, Sanjay Naithani. 2012. Bioethanol Production from Waste Paper Acid Pretreated Hydrolyzate with Xylose Fermenting Pichia Stipitis. Carbohydrate Polymers, 88: 825-829.

Balat M, Balat H, Cahide O. 2008. Progress in Bioethanol Processing. Proggres Energy Combust Sci, 34: 551-73.

Demirbas A. 2011. Competitive Liquid Biofuels from Biomass. Applied Energy, 88: 17-28.
Karimi K. Kheradmandinia S, Taherzadeh MJ. 2006. Conversion of Rise Straw to Sugars by Dilute Acid Hydrolysis. Biomass and Bioenergy, 30: $247-253$.

Kuhad, R. C., Gupta, R., Khasa, Y. P., \& Singh, A. 2010. Bioethanol Production from Lantana Camara (Red Sage) Pretreatment, Saccharification and Fermentation. Bioresource Technology, 101: 8348-8354.

Kumar, A., Singh, L., K., \& Ghose, S. 2009. Bioconversion of Lignocellulosic Fraction of WaterHyacinth (Eichhornia Crassipes) Hemicellulose Acid Hydrolysate to Ethanol by Pichia Stipitis. Bioresource Technology, 100: 3293-3297.

Limayem A. Ricke SC. 2012. Lignocellulosic Biomass for Bioethanol Production; Current Perspectives, Potential Issues and Future Prospects. Progres Energy Combust Sci, 38: 449-67.

Nibedita Sarkar, Sumanta Kumar Ghosh, Satarupa Bannerjee, Kaustav Aikat. 2012. Bioethanol Production from Agricultural Wastes: An Overview. Renewable Energy, 37: 19-27.

Teymouri, F., Laureano-Peres, L., Alizadeh, H., \& Dale, B, E. 2005. Optimization of the Ammonia Fiber Explosion (AFEX) Treatment Parameters for Enzymatic Hydrolysis of Corn Stover. Bioresource Technology, 96: 2014-2018. 
Saravana Kannan Thangavelu, Abu Saleh Ahmed, Farid Nasir Ani. 2014. Bioethanol Production from Sago Pith Waste Using Microwave Hydrothermal Hydrolysis Accelerated by Carbon Dioxide. Applied Energy, 128: 277-283. 